\title{
University extension and teacher training in Brazil: the Zoology Summer Course
}

\author{
Karla D. A. Soares ${ }^{1}$, Adriana M. Jeckel ${ }^{2}$, Gabriel de Moura Silva33, Victor Giovannetti , Kleber \\ Mathubara5
}

\begin{abstract}
Teacher training in higher education has been relatively neglected in Brazilian universities because postgraduate programs are mainly focused on the research that students produce. However, these postgraduate students are expected to become the next university and college professors. Herein, we present the experience of the Zoology Summer Course, a university extension course organized by graduate students from the Zoology Graduate Program at the University of São Paulo, Brazil. This course was created aimed to provide graduate students with an opportunity to develop and practice their teaching skills. To understand the influences, motives, and legacy of the CVZOO on its organizers, we developed a questionnaire and evaluated the responses by focusing on elements of academic formation and prospects for a teaching career, using systematic content analysis procedures as parameters. Our results demonstrate the importance of CVZOO as a space of dialogue and interaction for professional teacher training, as well as an opportunity to exchange experiences and build professional identity. The course has also influenced other academic activities such as the organization of scientific events, mentoring experience, and publications. Lastly, we discuss the importance of teacher training in Brazilian graduate programs and propose initiatives to improve the training of future university teachers.
\end{abstract}

Keywords: Graduation; Extension Course; Students; Biodiversity

\section{Extensão universitária e formação docente no Brasil: o Curso de Verão em Zoologia}

Resumo: A formação docente universitária tem sido bastante negligenciada em universidade brasileiras, uma vez que programas de pós-graduação focam majoritariamente na produção acadêmico-científica de seus alunos. No entanto, espera-se que os pósgraduandos sejam a próxima geração de professores universitários. Neste estudo, nós apresentamos a experiência do Curso de Verão em Zoologia da Universidade de São Paulo, Brasil. Este curso foi criado com o objetivo de proporcionar aos estudantes de pósgraduação a oportunidade de desenvolver e praticar suas habilidades para docência. No intuito de entender as influências, motivações e legado do CVZOO em seus organizadores, nós desenvolvemos um questionário e avaliamos as respostas buscando elementos da formação acadêmica e prospecção para a carreira docente, usando procedimentos de análise de conteúdo como parâmetros Os resultados demonstram a importância do CVZOO como um espaço de diálogo e interação com a prática docente bem como uma oportunidade para trocar experiências e construir uma identidade profissional. O curso tem influenciado em outras atividades acadêmicas, tais como organização de eventos científicos, orientação de alunos e publicações. Por fim, este artigo discute a importância da formação docente em programas de pós-graduação no Brasil e propõe algumas iniciativas para melhorar a formação dos futuros professores universitários.

Palavras-chave: Pós-Graduação; Curso de Extensão; Estudantes; Biodiversidade

\section{Submitted in \\ April 24, 2020 \\ Accepted in \\ August 21, 2020}

1

Laboratório de Ictiologia, Universidade de São Paulo, Programa de Pósgraduação em Zoologia, São Paulo, SP, Brasil.

karlad.soares@yahoo.com.br (correspondence author)

2 Laboratório de Anfíbios, Universidade de São Paulo, Programa de PósGraduação em Zoologia, São Paulo, SP, Brasil.

amjeckel@ib.usp.br

3

Laboratório de Educação Ambiental e Formação de Educadores,

Universidade de São Paulo, Programa de Pós-graduação em Interunidades, Brasil.

gmoura.bio@gmail.com

4

Laboratório de Ictiologia, Universidade de São Paulo, Programa de PósGraduação em Zoologia, São Paulo, SP, Brasil.vgiovannetti@gmail.com

5 Laboratório de Ictiologia, Universidade de São Paulo, Programa de Pósgraduação em Zoologia, São Paulo, $\mathrm{SP}$, Brasil.

kleber.leite@usp.br 


\section{Introduction}

The university is a social institution that aspires to universality and finds its normative and evaluative reference within society (Chauí, 2001). In Brazil, universities are structured according to the North American model, which has been influenced by German standards (Ministério da Educação, 1965). This institution is divided into two stages (undergraduate and graduate degrees) and essentially promotes scientific research, teacher training, and democratization of knowledge (Ministério da Educação, 1965). In addition, the university is a multidisciplinary institution with various purposes and centers of power, attending to different types of individuals and communities (Fórum de Pró-Reitores de Extensão das Universidades Públicas Brasileiras [FORPROEX], 1987; Soares \& Cunha, 2010).

In the early 1960s, the trinomial teaching-research-outreach redefined the concept of university, incorporating policies that contemplate concepts and guidelines for university extension in Brazil (Corrêa, 2007; Santos, 2010; de Mello et al., 2011; FORPROEX, 2012). The 1988 Constitution of the Federative Republic of Brazil states that universities have autonomous didactic-scientific, administrative, and financial management and must obey the principle of inseparability between teaching, research, and outreach. Thus, teaching, research, and outreach constitute the university's three basic functions and must be treated equally by higher education institutions; if they are unable to do so, they violate such legal precepts (Ministério da Educação, 1996; Santos, 2010; FORPROEX, 2012). In the 1990s, there were significant advances for the institutionalization of the university extension in Brazil (e.g., creation of the Funding Program to the University Extension [PROEXTE] in 1993; the law of guidelines and bases of national education (LDB) $n^{\circ} 9.394$ in 1996; creation of the National Plan of University Extension, in 1998) (FORPROEX, 2012), which significantly stimulated outreach activities.

Many studies have discussed the complexity of, along with the relations and peculiarities between, these three spheres, especially the challenges regarding teacher training and the role of university extension (Carneiro, 1985; Gisi \& Zainko, 2003; Corrêa, 2007; Oliveira \& Garcia, 2009; Santos, 2010; Soares \& Cunha, 2010). Outreach should be discussed and prepared thoughtfully among the university staff and students involved. Without proper training and teaching strategies, the whole university experience could become a negative one and lead to in mistakes such as the mere transmission of knowledge, mechanisms, messianism, cultural invasion, awareness prescription, and other factors that cause university members to conduct anti-dialogical, naive and oppressive actions (Freire, 1980). One of the main reasons why teacher training in higher education level has been quite neglected in Brazilian universities is because graduate programs primarily focus on the research aspect of students' formation. The overvaluation of research in Brazilian graduate programs follows the logic of 'academic productivism,' a phenomenon characterized by the excessive appreciation of the amount of scientific production generated in the academic sphere, which does not necessarily represent the quality, training, and well-being of graduate students (Sguissardi, 2010). Productivism is supported by evaluation systems that magnify scientific production, ultimately generating graduate assessment goals unfeasible for most graduate programs in Brazil. One consequence of this is that institutions end up focusing their effort on the 'supposed deficiencies,' and mostly invest in scientific knowledge acquisition.

When they exist, efforts for didactic development end up prioritizing technical aspects. The lack of a link between scientific knowledge and pedagogical practice in graduate programs reify, therefore, the hegemonic teacher training paradigm education, known as the model of technical rationality. This type of rationality is reinforced by the habitus of university teaching activity characterized by the abuse of content presentation (finished and determined) in expository classes as a functional strategy for transmitting information (Anastasiou \& Alves, 2005). In this sense, it is important to highlight the evident need for teacher training within the 
profession, which is focused on the development of human capital (effective training) of future teachers as opposed to the mere acquisition of scientific knowledge.

In this study, we present an outreach course that combines teacher training and university extension in the Zoology Graduate Program (in Portuguese, Programa de Pós-graduação em Zoologia [PPGZOO]) at the University of São Paulo (USP), and discuss the importance of promoting teaching experience for the professional careers of graduate students. Our goal was to evaluate the benefits such courses provide for constructing teaching careers within the scope of interdisciplinary practices, organization of scientific events, networking, publishing, mentoring, in addition to teaching practice, in terms of content selection, didactic planning, class strategies, and teacher-student interactions.

\section{Teacher training in Brazil}

Graduate Education in Brazil is officially regulated by the Technical Opinion 977/65 (Ministério da Educação, 1965), which has assigned higher education teacher training to graduate programs. However, according to Ludke (2005), the function of forming teachers to meet the demands of expanding higher education in Brazil was not discussed in detail. The subsequent opinions did not provide any reference to teacher training, suggesting that such training could be satisfied by deepening expertise in one specific discipline (Ministério da Educação, 1969; Soares \& Cunha, 2010).

The National Graduate Plan (in Portuguese, Plano Nacional de Pós-graduação [PNPG]), under CAPES's responsibility, shows that the federal government has had different priorities regarding graduate studies depending on the educational context and period. The II and III PNPGs, which were formulated from 1986 to 1989 and at the beginning of the New Republic (right after the military dictatorship dissolution to present), focus on the institutionalization and expansion of research as an instrument of scientific, technological, social, economic and cultural development, and its integration with the National Science and Technology System (Ministério da Educação, 1974, 1982, 1986). Since the 1990s, an emphasis on researcher formation has been assumed and consolidated as the graduate system's main objective, with policies directed towards it (Ministério da Educação, 1996, 2004; Paoli, 1998). One example is the evaluation processes of graduate programs that have been conducted by CAPES. According to Soares and Cunha (2010), who criticize the lack of pedagogical dimension in teacher training, one of the biggest failures of university teaching is the absence or scarcity of mechanisms to ensure qualified teachers' training. Most institutions' activities fundamentally prioritize academic productivity, mainly due to aspects evaluated by the government, with the results of such evaluations dictating how many resources get allocated to such programs.

PPGZOO students are not required to take classes or partake in undergraduate courses in any way. Only students with CAPES scholarships are required to take pedagogical preparation/internship courses through the Teaching Improvement Program (in Portuguese, Programa de Aperfeiçoamento de Ensino [PAE], 2016). This program is exclusively attended by graduate students enrolled at the University of São Paulo and primarily focuses on providing them with teaching experience and improving their didactic abilities. The program includes two stages: Pedagogical Preparation and Supervised Internship in Teaching. The Pedagogical Preparation can be structured depending on each PAE commission, using one of the following guidelines: a) graduate disciplines with content focused on higher education; b) conferences with educators discussing questions about higher education; c) core activities, involving preparation of didactic material, discussions about curriculum, discipline syllabus, and course planning coordinated by teachers. The Supervised Internship in Teaching involves graduate students participating in several dimensions, including, but not limited to, organizational, pedagogical, and evaluation issues in undergraduate courses, along with opportunities for teacher-student interactions in a classroom environment. According to the guidelines of Supervised Internship 
in Teaching, PAE students are allowed to teach at the discretion of a supervisor, as long as it does not exceed $10 \%$ of the total course hours (PAE guidelines, 2016).

The teacher training program at USP is limited regarding time and actual teaching performance for graduate students. Even though most of these students are paid during the semester that they work in the program, they are not considered university staff or have any worker's right when they are in the classroom assisting the principal lecturer. Also, graduate students' roles and importance in undergraduate courses have not been well established, which makes experience and training very irregular among these students. Nevertheless, for students who have never taken courses on teaching and its theoretical and practical aspects during their undergraduate studies, the PAE program is the only opportunity to learn and improve their teaching skills.

Students that participate in this teaching program are comparable to Graduate Teaching Assistants (GTA) from universities in the United States of America, Canada, and some European countries; however, each country and school has their own definition and regulation for the position (Rushin et al., 1997). In most universities, GTAs are usually considered staff and are expected to assist the lecturer in preparing laboratory supplies, grading, conducting review sessions, and sometimes even lecturing for part of the course. The training system is independent, and many surveys about the type and extent of training have been reported (e.g., Rushin et al., 1997; Luft et al., 2004; Gonsalves et al., 2009; Weidert et al., 2012). Prior experience and practice with teaching influence GTAs confidence and preparedness to teach (Dimitrov et al., 2014). Also, a GTA's efforts in making the lab experience better for the students positively impact student retention rates of science majors (O'Neals et al., 2007), showing the importance of investing in proper training for GTA. One example of targeted teacher training is the Center of Initiation (CIES) for future university teachers in France. Under the supervision of a teacher-tutor, participants perform teaching tasks such as practical classes and student mentoring and attend classes that deal with content about the university's function, organization of knowledge and didactic content, audiovisual techniques, among other topics (Soares \& Cunha, 2010). Even though not all universities have official GTA training (Gardner \& Jones, 2011), these Graduate Students play an important role in introductory Science courses, and, for better or worse, end up getting teaching experience that is valuable for future professional experience.

One strategy the graduate students from the Biosciences Institute of the University of São Paulo (IB-USP) found to deal with the limited opportunities to acquire teaching experience was to organize and teach summer and winter courses in their respective research fields. These courses are taught in four of the five departments at the IB-USP. Such initiatives are thriving along with other university extension efforts that involve undergraduate students and teachers and aim to include people from neighboring communities and undergraduate students from all South American countries. The ever-expanding university extension of the IB-USP is detailed in the Web-Documentary (Polesi et al., 2018).

Students of the PPGZOO created the Summer Course in Zoology (in Portuguese, Curso de Verão em Zoologia [CVZOO]) aimed at undergraduate students finishing their studies and interested in Zoology. Given that the main objective of the CVZOO course is to provide graduate students of the PPGZOO an opportunity to develop and practice their teaching skills, all classes are taught by members of the course's organizing committee. For eight editions, the CVZOO has been increasing its number of classes, workshops, debates, and activities (including activities at the Museum of Zoology of the University of São Paulo - MZUSP), expanding experiences and didactic strategies. Additionally, the course has promoted the exchange of knowledge between undergraduate students in Biological Sciences, from all regions of Brazil and South America, and PPGZOO graduate students with different backgrounds, origins, and experiences. Recently, positions have opened up for public high school teachers in São Paulo, aiming to help update their knowledge in Zoology. 


\section{A brief history of CVZOO}

In January 2013, after months of organizing under the supervision of Prof. Dra. Alessandra Bizerra, the PPGZOO graduate students, launched the CVZOO, and thirty undergraduate students from different states in Brazil came to USP to participate in the course, with no registration fees and free accommodations. Funded by the university, participants were housed at the Center of Sports Practices of USP (in Portuguese, Centro de Práticas Esportivas da Universidade de São Paulo [CEPE-USP]), and the university restaurant provided meals. Since the first edition, 312 undergraduate students from all regions of Brazil and other Latin American countries, as well as 55 public school teachers in São Paulo, have participated in the course. Students who want to participate in the CVZOO have to fill out an application form that provides information about their academic background and experience. Additionally, the applicant must include a cover letter explaining their main objectives and aspirations regarding the course and choose one of three animal groups: non-Panarthropoda invertebrates, Panarthropoda, and Vertebrates, according to their previous experience.

The course is two weeks long, with eight hours of classes per day. During the first week, classes address the main topics in Zoology, such as Philosophy of Science, Systematics, Evolutionary Processes, Paleontology, Biogeography, and other introductory topics. During the second week, classes focus on specific animal groups (e.g., Cnidaria, Chondrichthyes, among others) and techniques used in zoological studies.

As for grading criteria, student's attendance and participation in developing a Zoology research project are evaluated. Also, participants are asked to evaluate the course at the end of each day. Thus, students are encouraged to provide comments and suggestions to committee members about each class, teaching strategies, and speakers' resourcefulness.

In the present study, our main goals were to evaluate the course from the organizer's perspective, seeking to understand the impacts of CVZOO on those involved, and discuss the future of teacher training in graduate programs in Brazil.

\section{Material and Methods}

\section{Organizational process of CVZOO}

In order to execute the course during the third and fourth weeks of January, the PPGZOO graduate students interested in organizing the following CVZOO edition have to advertise the course to other graduate students and professors in the Zoology Department. This process begins with a short presentation about the course to explain its goals, format, as well as data about past editions, e. g., the number of applicants and how many alumni entered graduate programs. This presentation usually takes place around mid-April to early May to obtain a defined organizing committee in early June. After the organizing committee is formed, organizers are divided into subcommittees in charge of specific tasks, including course regulation, program content, outreach, admission, and budget. Monthly meetings are held in the Department to keep the entire committee informed about the different aspects of the course organization.

During the first month, organizers discuss any changes that will be made to the course format, goal, or targeted audience, and efforts focused on course regulation to get it approved by the regulatory branch at the University. Once the course is approved, the program content subcommittee defines the theoretical topics that will be covered during the first week of the course.

The course is advertised from June to the beginning of the course, mainly through its website and social media (e.g., Instagram and Facebook) through posts about each organizers' research line. Graduate students have an 
opportunity to disseminate their scientific research. Applications are received in September, and applicants are selected according to the criteria defined by the organization, which usually takes no more than two weeks following the application deadline. Afterward, a list of the selected applicants is posted on the course website.

Once the applicants are selected, organizers spend November and December preparing their lectures and activities for the topics which they volunteered for. Most subcommittees work on activities with a well-defined time span, except for the budget subcommittee, which works almost every month from early July until the course starts, raising enough money for the students' food and accommodation expenses. This is done by asking for grants from funding agencies such as CAPES, looking for partner companies such as laboratory supply dealers, and selling baked goods in the Department's common area.

\section{Research instruments and analysis}

To understand the influences, motives, and legacy of the CVZOO, we developed a questionnaire for the organizers and evaluated their responses by analyzing elements of academic formation and prospecting for teaching careers, using the systematic content analysis procedures as parameters (Bardin, 1977).

The questionnaire was created in Google Forms and sent to all CVZOO organizers from the first to the sixth editions (2013-2018; Supplementary material). The first part of the questionnaire focused on the respondents' profile to gather information about their undergraduate and graduate studies and the institutions where they got such degrees. We also asked them how many times and which editions they were part of the course's organization committee and if they were CVZOO alumni. The second part of the questionnaire contained open questions about their teaching and organizing experience during the course. One of the questions explicitly focused on how the course impacted their teaching practices, while another question focused on its impact on other academic activities. Participants were also encouraged to highlight positive and negative aspects of their teaching experiences, as well as include suggestions about how the course organization could be improved. In addition to the questions, respondents were encouraged to write about their experience in a free writing section. The questionnaire was open for two months (February 20th, April 19th, 2018). All respondents authorized the publication of the data obtained. All responses were analyzed in NVivo 12.5.0, and the Figure 1 was created using CmapTools 6.03.01.

\section{Results and Discussion}

During the six editions of CVZOO analyzed in this study (2013-2018), a total of 70 graduate students contributed to the organization. In total, $45.7 \%$ of the organizers answered the questionnaire, with the main points and responses summarized in Figure 1.

The most common motive for participating in the course organization committee was the desire to improve their teaching practice $(90.6 \%)$, followed by interaction with fellow graduate students $(71.9 \%)$ and curriculum vitae improvement (56.3\%). Such results demonstrate the importance of CVZOO as a space for dialogue and interaction about the professional teacher training, as well as to exchange experiences and build professional identity (Pelizzari et al., 2002; Vasconcelos et al., 2003). Besides, five respondents (15.6\%) cited their desire to disseminate their laboratory research lines. The desire to disseminate scientific knowledge to students from different universities and regions of Brazil helps popularize science, decentralize academic knowledge, and promote dialogue (Germano \& Kulesza, 2007). One of the basic principles of outreach activities is the interaction between the University and society. A University cannot consider itself the owner of the knowledge 
offered to society; conversely, it must be an active participant in society, disseminating knowledge and being sensitive to problems and appeals (FORPROEX, 2012).

When asked about the challenges during the organization of CVZOO, raising funds was the most frequently cited challenge (76.3\%). This step requires a lot of effort from the entire committee in order to cover participants' food and lodging expenses. Although fundraising is not mandatory for the event, we believe that food and accommodation should not be a limiting factor for students attending the CVZOO.

Regarding the answers obtained about the impacts of CVZOO on their professional lives, two analysis categories are presented and discussed in detail: teaching practice and other academic activities.
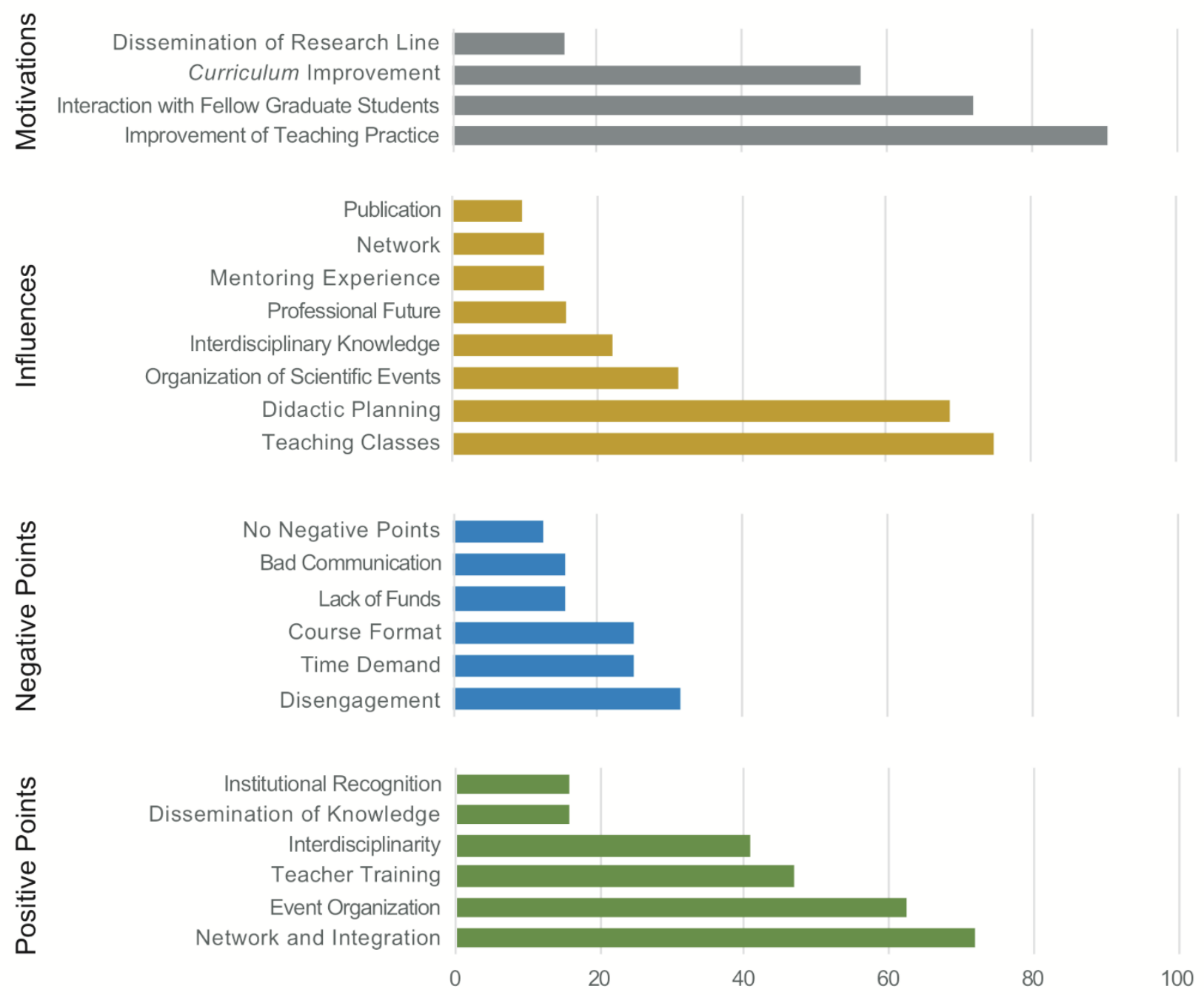

Percentage

Figure 1. Percentage of responses per category and question. The categories were created based on qualitative analysis of responses; hence, respondent answers may include more than one category per question. 


\section{The influence of CVZOO on teaching practice}

The experience of CVZOO organizers meets two of the courses' main goals, 1) to create more opportunities for graduate students to obtain teaching experience and 2) to expose these students to different research lines.

Concerning teaching experience, two main points that respondents emphasized were teaching classes (75\%) and didactic planning (68.8\%). Five respondents mentioned that the CVZOO was their first experience with teaching long classes and for a large audience. Usually, graduate students have little or no experience in teaching classes. Their experiences with presenting ideas and concepts are restricted to seminars and meetings about very specific topics-mainly about their research projects-in situations where interaction with the audience is minimal.

The teaching practice that the organizers gained during CVZOO allowed them to find out "how enjoyable it is to teach", as one organizer stated; adding that their desire to become a teacher "increased a lot ". The experience of being the main lecturer in a classroom was extremely important to understand their role in a learning environment and to feel more comfortable in future teaching situations. Such confidence in the classroom also allowed them to enjoy interactions with their audience (over 50 undergraduate students) and helped them realize the importance of content selection and didactic planning. The student-teacher interaction was necessary for the organizers as it exposed them to different teaching experiences, which helped them construct their own teaching identity. One responder also mentioned the importance of student feedback about the classes to improve didactic techniques and reinforce student participation in meaningful content learning (Ausubel, 1982; Pelizzari et al., 2002; Santos et al., 2016).

During the course planning, the organizers generally choose themes related to their research, which helped to make them feel more comfortable during this new experience. However, in some cases, organizers had to teach classes outside of their field of expertise. When asked about teaching subjects outside of their research projects, many organizers reported that it was challenging and took hard work to prepare their classes, but that it was also exciting and gratifying since most had to review basic biological knowledge and organize their ideas from there. Basically, this is what undergraduate students have to do to understand the subject, which made the didactic planning more efficient. Those who taught classes outside their interests recognize these values; one participant said: "It is challenging, but I think it is necessary. We have to get out of the comfort zone of our projects and expand our knowledge to other areas during our graduate training". Another responder mentioned that giving classes outside of her expertise "is a great responsibility since students rely on the content and references transmitted [in class] to seek more information on the subject." Such statements demonstrate that teaching subjects that are not related to one's research area expands horizons and encourages an active and responsible posture during teacher training. When teaching about various topics, the organizers develop the ability to articulate different knowledge dimensions and promote interdisciplinarity (Coelho, 2014).

Only two organizers stated that non-experts should not teach subjects as they felt students should be offered the highest quality classes. However, in Brazil, most university professors end up teaching classes that do not lie within their field of expertise at some point in their careers, and we believe that students should be able to explore these kinds of challenges in less formal experiences. Some respondents added that teaching classes that were not specifically related to their research fields helped them applying for jobs as university teachers. It is noteworthy that most doctoral professors trained at USP end up teaching at other universities with unique needs and organizations, which require an interdisciplinary view, as well as the ability to meet curriculum demands.

Most Brazilian undergraduate courses are characterized by a fragmented formation that makes knowledge integration difficult and does not stimulate students' interests or critical thinking (Gatti \& Nunes, 2009; Gatti, 
2010). Frequently, knowledge is compartmentalized, and the teaching of contents is decontextualized and unproblematized, which leads to memorization learning (Anastasiou \& Alves, 2009; Pereira dos Santos, 2012). Professors who do not teach subjects outside their research area miss an opportunity to think outside the box and improve their own teaching and research skills. Most of the organizers had no prior experience in planning undergraduate-level classes before CVZOO. As explained earlier, most teaching practices for graduate students at USP and many universities around Brazil are restricted to assisting courses and giving brief presentations, often including straightforward tasks within the teaching profession, e.g., taking attendance in the classroom and providing assistance in laboratory classes. One of the organizers highlighted the lack of opportunities during her education, stating: "It is rare to have the opportunity to really plan, elaborate and lecture an entire class". For most organizers, their CVZOO class was the first time they planned a $1 \mathrm{~h} 50 \mathrm{~min}$ class, which requires studying, selecting, and organizing relevant content. Regarding this topic, organizers pointed out their difficulties with 1) class preparation, 2) properly organizing the class to fit the determined time, and 3) selecting different didactic strategies. The organizers believe that preparing a lesson is a task that requires careful planning regarding the content and methods used to facilitate learning. Through class planning, teachers outline the learning objectives and reflect on their practice, thus improving the quality of teaching (Santos $\&$ Perin, 2013). Such considerations demonstrate how complex teaching is and that is not restricted to the classroom.

Cunha (2006) listed some skills related to the teaching profession, such as planning teaching activities and recognizing multiple didactic and evaluative strategies. Such abilities are not innate and need to be developed collectively through appropriate teacher training. On this, Garcia (1999) stated: "The formation of this professional [teacher] needs to ensure a link between theory and practice, taking into account the epistemological reflection of practice. "However, the training of a university teacher has been predominantly intuitive and imitative. Most organizers are still trapped in traditional expository classes, and even though they know that it is not the best way, they do not have the background knowledge to change. Unfortunately, teaching skills and didactic knowledge are not encouraged during graduate formation, so the foremost example of lectures stems from the way such content has been addressed (and still is) by their own professors, i.e., the "self-taught posture" of Benedito et al. (1995).

In most Brazilian institutions, there is a predominance of unpreparedness and even a lack of scientific knowledge in the teaching/learning process, which is only perceived the moment teachers enter the classroom. Generally, disciplines that a lecturer teaches are predetermined, and they must plan them individually and solitarily. Therefore, they do not receive any guidance about planning, methodology, or evaluation processes, and they do not have to make reports (Anastasiou, 2011). In general, opportunities to discuss teaching practices are scarce and not stimulated by university teachers. As pointed out by Benedito et al. (1995), "teaching itself has been seen with excessive reductionism when identified only with the activities that teachers perform when they are in the classroom with their students."

The CVZOO not only promotes teaching opportunities but is an opportunity for dialogue about teacher training and its peculiarities. However, the course has received little help and recognition from most professors in the Zoology Department. Although the CVZOO seems to instill confidence in future zoologists to teach classes, department professors are missing out on a significant opportunity to participate in the training of future teachers.

\section{Impact of CVZOO on other academic activities}

Regarding the lack of teaching experience, most of the organizers' mentioned how CVZOO has positively impacted by providing an opportunity for them to practice teaching. However, some of them also highlighted 
how CVZOO had enhanced some of the academic activities that are not directly related to their research project. The following five aspects emerged regarding how the course influenced their academic activities: organization of scientific events (31.3\%), interdisciplinary knowledge (21.9\%), networking (12.5\%), mentoring experience (12.5\%), and publications (9.4\%).

\section{Organization of scientific events}

About $31 \%$ of respondents reported being positively influenced by the experience of organizing the CVZOO. Several steps involving many people, university sectors, and specific documents are required to organize CVZOO, which provides opportunities for organizers to deal with bureaucratic and organizational issues. Such experience encompasses the bureaucratic, administrative, logistic, and financial aspects of organizing a scientific event. One organizer said, "it added tremendously to the experience of organizing events (from the bureaucratic part to the execution)." According to Gomes (1981), scientific events are the best and most efficient way of promoting interaction among researchers and improving the oral communication of knowledge. The experience of organizing and promoting the CVZOO was important in the formation of new researchers, as well as for the dissemination of knowledge produced at USP.

\section{Interdisciplinarity}

As previously stated, the emphasis on research and the structural division among departments reinforce students' isolation in their own field of study. In addition to organizing a class outside their research topic, the fact that organizers had to study and recall many of the concepts and ideas from different subjects made them realize the importance of interdisciplinarity for teaching experience and their research development. Based on their answers, their experience in CVZOO encouraged them to study different subjects and expand ideas outside their own research topic. One said: "the CVZOO allowed me to learn from other zoology areas that I was not familiar with." By understanding that different subjects are connected through specific points in knowledge, and that results obtained by one subject can and will interfere in other research lines, a researcher weaves links between both areas for a single purpose and truly experience the importance of interdisciplinarity (Gattás \& Furegatto, 2007). Such experiences help expand and establish professional partnerships and interdisciplinary projects.

\section{Networking}

Some of the respondents reported that CVZOO promotes a network of contacts among organizers, students, speakers, and other lecturer guests. One organizer said: "we learned and improved upon ways to relate with other people (undergraduate students, fellow graduate students, employees of the institute, and professors). 'Many studies have discussed the importance of student socialization (Delamont et al., 1997a, 1997b; Weidman \& Stein, 2003; Sinclair et al., 2014). Weidman and Stein (2003) proposed three categories of "socialization": participation in scholarly activities, student-faculty and student-peer interactions, and supportive faculty environment. CVZOO creates an environment that promotes interaction among all course participants, allowing them to exchange experiences and skills and make the course a place to make professional connections. CVZOO organizers with different backgrounds form a network of professionals who can share their unique lives and professional histories and experiences. Moments of socialization between students from different research areas are essential for constructing and reproducing knowledge, as demonstrated by previous studies (Delamont et al., 1997a, 1997b). Weidman and Stein (2003) pointed out that students who are effectively socialized in scholar practices may have advantages in their development as active 
researchers. Research cultures differ depending on the study area (Deem \& Brehony, 2000); thus, "socialization" appears not only to be an additional or optional extra, but a central point of academic life (Sinclair et al., 2014).

\section{Mentoring}

Another important aspect that some organizers (12.5\%) highlighted is student mentoring and new researchers' training. During the CVZOO, organizers act as mentors for the course attendees, helping them think scientifically and develop research projects. Such an opportunity is unique since graduate students rarely have a chance to develop these skills while obtaining their degrees. Even though it is a short time, these mentoring moments are very important for graduate students to become aware of the challenges in mentoring and managing a lab crew. Paglis et al. (2006) stated that student advising and mentoring are the essential skills for a university professor to have and can be divided into three dimensions: collaboration on research publication, psychosocial mentoring and career commitment, and their effects on doctoral candidates five years after commencement. The mentor helps students develop their research skills through empathy, encouragement, responsiveness to questions regarding competence, commitment, and sharing professional experiences (Paglis et al., 2006). Zellers et al. (2008) summarized all dimensions and characteristics of a good mentor as "someone who cares." Sinclair et al. (2014) argued that this particular nature of supervision could directly affect whether a candidate becomes an active researcher and how long the effects of such supervision last.

\section{Publication}

Throughout the world, a key marker of an active researcher is productivity, which is measured by the number of publications a researcher has. Among respondents, about $9 \%$ were influenced or stimulated to publish. As mentioned above, CVZOO yielded publications in annals of congresses (Soares et al., 2018) and the book, "Tópicos de pesquisa em Zoologia" (Beneti et al., 2017), about the main topics covered during the first week of the course. Besides, scientific writing, such as dissertation and thesis chapters, was also enhanced by preparing and executing the lectures. "I reviewed topics in phylogeography to teach the lessons and write the [thesis] chapter", said one organizer.

\section{Conclusion and Perspectives}

Through CVZOO, graduate students' teaching practice from the Zoology Graduate Program of the University of São Paulo has been improved by creating opportunities to share teaching experiences, reflect on teaching strategies, and exchange knowledge among graduate and undergraduate students. Additionally, graduate students are asked to think about career progression as university teachers and researchers and reflect on university extension's democratic and unifying role. A summary of the activities performed by PPGZOO students and the main contributions of CVZOO are shown in Figure 2.

Since the 1990s, university extension has been considered a space that enables social and institutional interaction in a wide variety of dimensions to disseminate and create new ideas (Oliveira \& Garcia, 2009). Additionally, the extension can be defined as an interdisciplinary work that favors social integration, the democratization of academic knowledge, and the effective participation of the community in the work of the University to update and redefine its research and teaching (according to the 1988 Brazilian Federal Constitution). Nogueira (2001) proposed the following five guidelines for formulations and actions of university extension: Dialogic interaction, Interdisciplinarity and Interprofessionality, Inseparable Teaching-ResearchExtension, Impact on Student Training, Impact and Social Transformation. The rationality model of teaching represented by specialists that dominate specific topics of a specific area that are unrelated to contemporary society's needs and not committed to meaningful student learning is still a reality in most universities, and it is 
doomed to fail. Behrens (2007) pointed out that universities should break from the conservative paradigm and focus on qualified professionals challenged to modify and transform their role as a teacher with critical and reflective awareness.

It is necessary to be aware that at University's commitment to society is not spontaneous; it is linked to management policies and institutional guidelines that create conditions for the promotion of actions, which mobilize the transformation of teaching pedagogical practices, student activity, and the community in which the University is located (Santos, 2010). Therefore, university extension needs to be incorporated into universities' institutional projects to avoid being a group of isolated actions (Oliveira \& Garcia, 2009).

\section{Obligation and other Activities of Graduate Students}

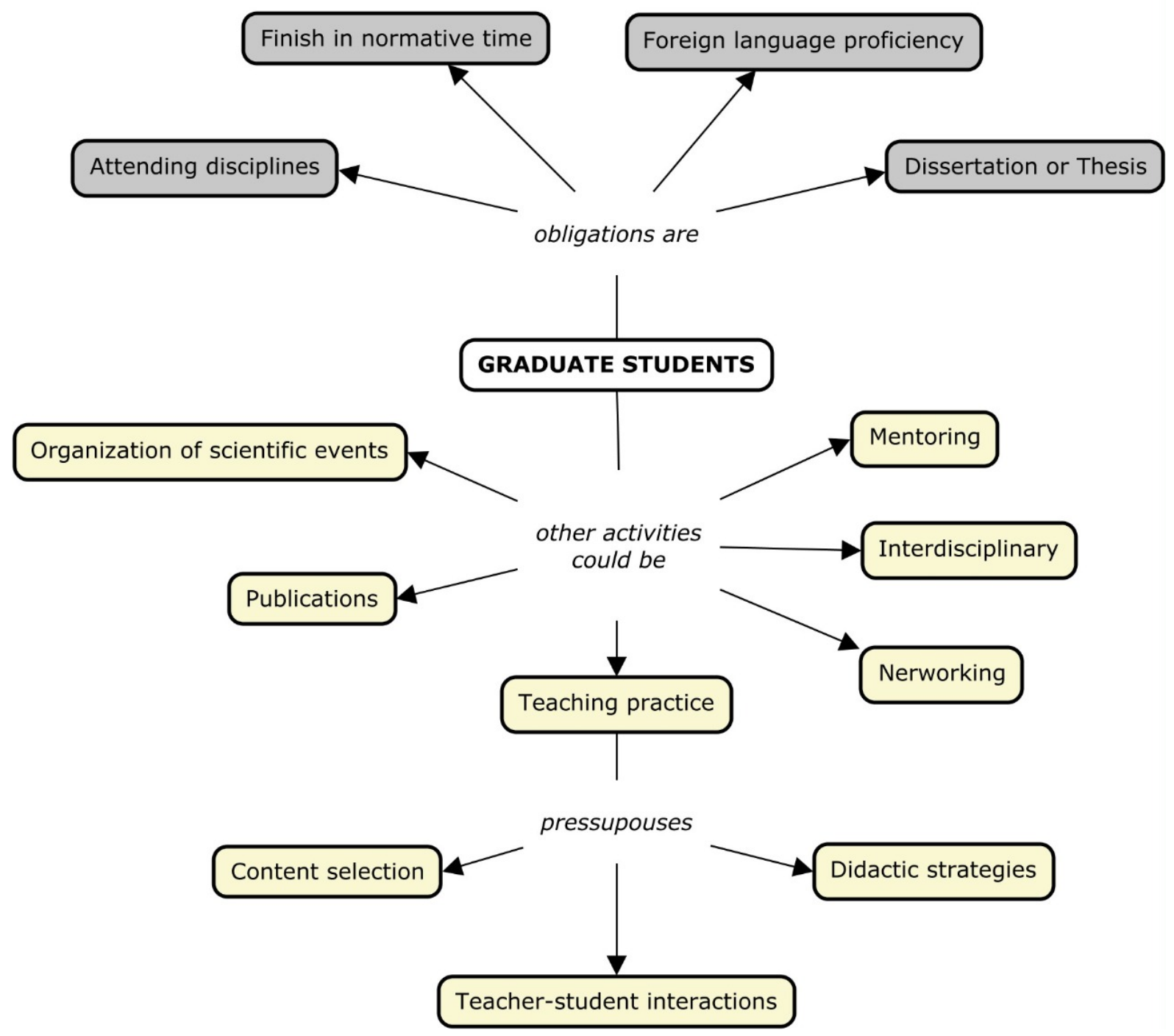

Figure 1. Obligations and other activities of Graduate Students. Gray: required activities for graduate students according to graduation program norms. Yellow: other activities that CVZOO has influenced regarding graduate formation. 
Graduate programs tend to concentrate their actions to meet the demands of academic productivism, measuring the quality of doctoral programs by the number and impact of publications, and ignoring teaching practices or other aspects of academic background. There is no broad debate about the programs which, faced with competition for resources, are forced to meet demands, rather than confront them. That is the current reality for the PPGZOO and many graduate programs around Brazil. The emphasis on researcher formation and pressures for maintaining high scientific productivity has contributed to distance students from teaching experiences. Teaching and research present differences in their constituent elements and activities and often compete for space (Pimenta \& Anastasiou, 2002). As only research is rewarded, teaching loses values within the university culture (Pachane \& Pereira, 2004). In this sense, the CVZOO as an activity of university extension promotes the articulation between research and teaching, helping graduate students develop autonomy in learning how to teach (Santos, 2010; Santos et al., 2016).

Thus, we think that Brazilian graduate programs and universities should reevaluate their policies and stimulate a collective reflection related to didactics and mutual support among teachers and students, aiming to improve the quality of the teaching-learning process. Creating spaces for teachers and students to share teaching experiences like seminars and discussion forums, and reviewing the forms of recruitment and career progression of the university professor, while highlighting the importance of organization of knowledge and didactic content are some of the initiatives that have been proposed by Soares and Cunha (2010). Furthermore, the institution of internal and external partnerships in interdepartmental and interdisciplinary activities with diverse social sectors could help build new knowledge and develop skills to solve problems in the contemporary world (Ferreira, 2010; Costa \& Silva, 2011; dos Santos, 2012).

Lastly, considering the current scenario characterized by the federal government's neglect and investment cuts for education and science, we should join efforts to promote the intersection of scientific knowledge and society, extending the public University beyond its walls and allowing academics to learn during the process. Knowledge must be accessible, which has been exemplified by the CVZOO initiative.

\section{Acknowledgements}

The authors would like to thank all the organizers and participants who have made it possible to run the CVZOO throughout these years. We thank Prof. Alessandra Bizerra for supervising the course; and all the respondents for their feedback and comments which made this study possible. We also thank the Zoology Graduate Program, Biosciences Institute and the University of São Paulo, as well as the technicians of the Zoology Department for providing support during classes. This study was financed in part by the Coordenação de Aperfeiçoamento de Pessoal de Nível Superior - Brasil (CAPES) - Finance Code 001. K. D. A. S. was funded by CAPES (Finance Code 001) and Fundação de Amparo à Pesquisa do Estado de São Paulo (FAPESP Proc. 2014/20316-5). A. M. J. was funded by FAPESP (Proc. 2016/09999-9). G. M. S. was funded by CAPES (Finance Code 001). V. G. was funded by (CNPq 142195/2015-4). K.M. was funded by Master's and PhD's fellowship from CAPES-PROEX (Proc. 8749764832218320). We thank Hannah Lois Doerrier (HD translation) for reviewing the manuscript's English.

\section{Contributions of the authors}

K.D.A.S., A.J., G.M.S., V.G., and K.M. came up with the concepts for and wrote the final text; G.M.S helped analyze the responses in NVivo 12.5.0; K.D.A.S. and K.M. created the questionnaires in Google Forms and sent it to all respondents. 


\section{References}

Anastasiou, L. G. C. (2011). Processos formativos de docentes universitários: Aspectos teóricos e práticos. In S. G. Pimenta \& M. I. Almeida. (Eds.), Pedagogia universitária: Caminhos para a formação de professores. (pp. 44-74). São Paulo: Editora Cortez.

Anastasiou, L. G. C., \& Alves, L. P. (2005). Estratégias de ensinagem. In L. G. C. Anastasiou \& L. P. Alves (Orgs.). Processos de ensinagem na universidade: pressupostos para as estratégias de trabalho em aula. (p. 67-100). 3. ed. Joinville: Univille.

Ausubel, D. P. (1982). A aprendizagem significativa: A teoria de David Ausubel. São Paulo: Moraes.

Bardin, L. (1977). Análise de conteúdo. Lisboa, Portugal: Edições 70.

Behrens, M. A. (2007). O paradigma da complexidade na formação e no desenvolvimento profissional de professores universitário. Educação, 3(63), 439-455.

Benedito, V., Paiva, V. S. F., \& Ferrer, V. (1995). La formación universitária a debate. Barcelona, Spain: Universitat de Barcelona.

Beneti, J. S., Montesinos, R., \& Giovannetti, V. (2007). Tópicos de pesquisa em Zoologia. São Paulo, Brasil: Instituto de Biociências, Universidade de São Paulo.

Carneiro, M. A. (1985). Extensão universitária: Versão \& perversões - Estudo tentativo de identificação do débito social das universidades federais do Nordeste. Rio de Janeiro: Presença Edições.

Chauí, M. de S. (2001). Escritos sobre a universidade. São Paulo: Editora da UNESP.

Coelho, G. C. (2014). o papel pedagógico da extensão universitária. Em Extensão, 13(2), 11-24.

Corrêa, E. J. (Org.) (2007). Extensão Universitária. Organização e sistematização / Fórum de Pró-Reitores de Extensão das Universidades Públicas Brasileiras Coordenação Nacional do FORPROEX. - Belo Horizonte: Coopmed.

Costa, A., \& Silva, P. B. (2011). Extensão universitária brasileira: Possibilidades, limitações e desafios. São Paulo: Nelpa.

Cunha, M. I. A. (2006). Trajetórias e lugares de formação da docência universitária: Da perspectiva individual ao espaço institucional a ser realizado. São Leopoldo: Unisinos, PPGedu.

Deem, M. R., \& Brehony, K. (2000). Doctoral students access to research cultures - Are some more equal than others? Studies in Higher Education, 25(2), 149-165.

Delamont, S., P., Atkinson, P., \& Parry, O. (1997a). Critical mass and doctoral research: Reflections on the Harris Report. Studies in Higher Education, 22(3), 319-331.

Delamont, S., Parry, O., \& Atkinson, P. (1997b). Critical mass and pedagogic continuity: Studies in academic habitus. British Journal of Sociology of Education, 18(4), 533-549.

Dimitrov, N., K., Meadows, E. D. H., Kustra, T., Ackerson, L., Prada, N., Baker, N., \& Potter, M. K. (2014). Assessing graduate teaching development programs for impact on future faculty. Toronto: Higher Education Quality Council of Ontario.

Ferreira, A. P. (2010). Gestão universitária: Teoria e prática. Rio de Janeiro: Rosa dos Tempos.

Fórum de Pró-Reitores de Extensão das Universidades Públicas Brasileiras. (1987). I Encontro de Pró-reitores de extensão das universidades públicas brasileiras. Brasília: FORPROEX. Retrieved from http://www.renex.org.br Ldocumentos/EncontroNacional/1987-I-Encontro Nacional-do-FORPROEX.pdf

Fórum de Pró-Reitores de Extensão das Universidades Públicas Brasileiras. (2012). XXXI Encontro de Pró-reitores de extensão das universidades públicas brasileiras. Manaus: FORPROEX. Retrieved from https://www.ufmg.br/proex/ renex/images/documentos/2012-06-28-310-Encontro-Nacional-Manaus.pdf

Freire, P. (1980). Extensão ou Comunicação? 5. ed. Rio de Janeiro: Paz e Terra.

Freire, S. M. (2011). Desafios da Extensão Universitária na Contemporaneidade. Revista Conexão UEPG, 7(1), 8-15.

Garcia, C. M. (1999). Formação de professores: Para uma mudança educativa. Lisboa: Porto. 
Gardner, G. E., \& Jones, M. G. (2011). Pedagogical preparation of the science graduate teaching assistant: Challenges and implications. Science Educator, 20(2), 31-41.

Gattás, M. L. B., \& Furegato, A. R. F. (2007). A interdisciplinaridade na Educação. Revista da Rede de Enfermagem do Nordeste, 8(1), 85-91

Gatti, B. A. (2010). Formação de professores no Brasil: Características e problemas. Educação \& Sociedade, 31(113), 1355-1379.

Gatti, B. A., \& Nunes, M. M. R. (2009). Formação de professores para o ensino fundamental: Estudo de currículos das licenciaturas em Pedagogia, Língua Português, Matemática e Ciências Biológicas. São Paulo: Textos FCC.

Germano, M. G., \& Kulesza, W.A. (2007). Popularização da ciência: Uma revisão conceitual. Caderno Brasileiro de Física, 24(1): 7-25.

Gisi, M. L., \& Zainko, M. A. S. (Orgs.) (2003). Políticas e gestão da educação superior. Florianópolis/Curitiba: Insular/Champagnat.

Gomes, H. E. (1981). Como vai o sistema de comunicação na ciência da informação? Ciência da Informação, 10(1), 7173.

Gonsalvez, A. J., Harris, D., \& McAlpine, L. (2009). The zones framework for both teaching and learning: Application to graduate student teaching assistants. Journal of Further and Higher Education, 33(3), 205-218.

Ludke, M. (2005). Influências cruzadas na constituição e na expansão do sistema de pós-graduação stricto sensu em educação no Brasil. Revista Brasileira de Educação, 30, 117-123.

Luft, J. A., Kurdziel, J. P., Roehrig, G. H., \& Turner, J. (2004). Growing a garden without water: Graduate teaching assistants in introductory science laboratories at a doctoral/research university. Journal of Research in Science Teaching, 41(3), 211-233.

De Mello, J. M. C., Maculan, A., \& Renault, T. B. (2011). Brazilian universities and their contribution to innovation and development. In B. Göransson \& C. Bundenius (Eds.), Universities in transition: The changing role and challenges for academic institutions. (pp. 54-77), Ottawa: Springer International Development Research Centre.

Ministério da Educação (1965). Parecer 977/65. Brasília: MEC/CFE, 44, 67-86.

Ministério da Educação (1969). Parecer 77/69. Brasília: MEC/CFE, 98, 128-132.

Ministério da Educação (1974). I Plano Nacional de Pós-Graduação. Brasília: MEC/CAPES.

Ministério da Educação (1982). II Plano Nacional de Pós-Graduação 1982-1985. Brasília: MEC/CAPES.

Ministério da Educação (1996). III Plano Nacional de Pós Graduação 1986-1989. Brasília: MEC/CAPES.

Ministério da Educação (2004). V Plano Nacional de Pós-Graduação (2005-2010). Brasília: MEC\CAPES. Retrieved from http://www.capes.gov.br/sobre-a-capes/plano-nacional-de-pos-graduacao

Nogueira, M. D. P. (2001) (Org.). Extensão Universitária: diretrizes conceituais e políticas: documentos básicos do Fórum de Pró-Reitores de Extensão das Universidades Públicas Brasileiras. Belo Horizonte: PROEX/UFMG.

Oliveira, T. M. N., \& Garcia, B. R. Z. (2009). A extensão e o seu papel na formação acadêmica. Revista Univali, 14(1), 111117.

O'Neals, C., Wright, M., Cook, C., Perorazio, T., \& Purkiss, J. (2007). The impact of teaching assistants on student retention in the sciences. Journal of College Science Teaching, 36(5), 24-29.

Pachane, G. G., \& Pereira, E. M. A. (2004). A importância da formação didático-pedagógica e a construção de um novo perfil para docentes universitários. Revista Iberoamericana de Educación, 35(1), 1-13.

Programa de Aperfeiçoamento de Ensino (2016). Diretrizes para a proposição das disciplinas da Etapa de Preparação Pedagógica. Universidade de São Paulo: Pró-Reitoria de Pós-graduação. Retrieved from http://www.prpg.usp.br/ attachments/article/631/Diretrizes\%20para\%20disciplina\%20de\%20EPP\%20-\%2029-09-2016.pdf

Paglis, L. L., Green, S. G., \& Bauer, T. N. (2006). Does adviser mentoring add value? A longitudinal study of mentoring and doctoral student outcomes. Research in Higher Education, 47(4), 451-476. 
Paoli, N. J. (1998). O princípio da indissociabilidade do ensino e da pesquisa: Elementos para uma discussão. Cadernos CEDES, 22.

Pelizzari, A., Kriegl, M. L., Baron, M. L, Finck, N. T. L., \& Dorocinski, S. I. (2002). Teoria da aprendizagem significativa segundo Ausubel. Revista PEC, 2(1), 37-42.

Pereira dos Santos, M. (2012). Extensão universitária: Espaço de aprendizagem profissional e suas relações com o ensino e a pesquisa na Educação Superior. Revista Conexão UEPG, 8(2), 154-163.

Pimenta, S. G., \& Anastasiou, L. das G. C. (2002). Docência no Ensino Superior. São Paulo: Cortez (coleção Docência em Formação v. 1).

Polesi, C., Sato, M. K., Bizerra, A. F., Franchi, N., Rocha, P. E. D., \& Silva, D. A. (2018) Vida na extensão (Web Documentary). São Paulo, Brasil: Instituto de Biociências. Retrieved from http://vidanaextensao.ib.usp.br/\#introdução

Rushin, J. W., Saix, J., Lumsden, A., Streubel, D. P., Summers, G., \& Bernson, C. (1997). Graduate teaching assistant training: A basis for improvement of college biology teaching \& faculty development? The American Biology Teacher, 59(2), 86-90.

Santos, J. H. S., Rocha, B. F., \& Passaglio, K. T. (2016). Extensão universitária e formação no ensino superior. Revista Brasileira de Extensão Universitária, 7(1), 23-28.

Santos, M.L., \& Perin, C.S.B. (2013). A importância do planejamento de ensino para o bom desempenho do professor em sala de aula. Paranavaí: Cadernos PDE.

Santos, M. P. (2010). Contributos da extensão universitária brasileira à formação acadêmica docente e discente no século XXI: Um debate necessário. Revista Conexão UEPG, 6(1), 10-15.

Sguissardi, V. (2010). Produtivismo acadêmico. In Oliveira, D. A.; Duarte, A.; Vieira, L. (Org.). Dicionário de trabalho, profissão e condição docente. Belo Horizonte: Faculdade de Educação UFMG.

Sinclair, J., Robyn, B., \& Denise, C. (2014). How the doctorate contributes to the formation of active researchers: what the research tells us. Studies in Higher Education, 3(10), 1972-1986.

Soares, K. D. A, Mathubara, K. L., Lawley, J. W., Ribeiro, G. M., Bottallo, A. A. Q., Tiseo, G. R., \& Rodrigues, I. S. C. (2018). Curso de verão em Zoologia: da Universidade de São Paulo para a América Latina. Anais e Resumos do Congresso Brasileiro de Zoologia, Foz do Iguaçu, 32. (pp. 692-692). Foz do Iguaçu, Brazil: UNILA.

Soares, S. R., \& Cunha, M. I. (2010). Formação do professor: A docência universitária em busca de legitimidade. Salvador, Brazil: EDUFBA.

Vasconcelos, C., Praia, J. F., \& Almeida, L. S. (2003). Teorias de aprendizagem e o ensino/aprendizagem das ciências: Da instrução à aprendizagem. Psicologia Escolar e Educacional, 7(1), 11-19.

Weidman, J. C., \& Stein, L. E. (2003). Socialization of doctoral students to academic norms. Research in Higher Education, 44(6), 641-656.

Weidert, J. M., Wendorf, A. R., Gurung, R. A. R., \& Filz, T. (2012). A Survey of graduate and undergraduate teaching assistants. College Teaching, 60(3), 95-103.

Zellers, D. F., Howard, V. M., \& Barcic, M. A. (2008). Faculty mentoring programs: Reenvisioning rather than reinventing the wheel. Review of Education Research, 78(3), 552-88.

How to cite this article:

Soares, K. D. A., Jeckel, A. M., Silva, G. de M., Giovannetti, V., \& Mathubara, K. (2020). University extension and teacher training in Brazil: The Zoology Summer Course. Revista Brasileira de Extensão Universitária, 11(3), 315-330. https://periodicos.uffs.edu.br/index.php/RBEU/article/view/11475/pdf 